\title{
Bacterial communities of juvenile corals infected with different Symbiodinium (dinoflagellate) clades
}

\author{
Raechel A. Littman ${ }^{1,2}$, Bette L. Willis ${ }^{2}$, David G. Bourne ${ }^{1, *}$ \\ ${ }^{1}$ Australian Institute of Marine Science, PMB 3 Townsville, Queensland 4810, Australia \\ ${ }^{2}$ ARC Centre of Excellence for Coral Reef Studies, and School of Marine and Tropical Biology, James Cook University, \\ 101 Angus Smith Drive Townsville, Queensland 4811, Australia
}

\begin{abstract}
The coral holobiont consists of the host and its microbial partners, including the dinoflagellate endosymbiont Symbiodinium and bacteria living both on and within coral tissues. Although genetically different, Symbiodinium types have been shown to differentially affect the physiology of the coral host; their effects on the bacterial partners in the association are unknown. The present study compares profiles of the bacterial communities associated with juvenile corals of Acropora millepora and A. tenuis that had been experimentally infected with 2 different clades of Symbiodinium, Clade C1 and D, to investigate possible interactions between bacterial and Symbiodinium communities. Three culture-independent 16S rRNA gene profiling methods (clone library construction, terminal restriction length polymorphism and denaturing gradient gel electrophoresis) revealed no discernible pattern in bacterial communities on 9 mo old juvenile corals containing different clades of zooxanthellae, suggesting that coral-associated bacteria are not linked to Symbiodinium types in hospite in early ontogeny. In contrast to bacterial profiles of adult corals, bacterial communities associated with juvenile corals were highly variable, indicating that bacterial associates are not conserved in these early stages. When 12 mo old juveniles were sampled again in summer, bacterial communities associated with $A$. tenuis hosting Clade D Symbiodinium were dominated by sequences affiliating with Vibrio species, indicating that corals harbouring this symbiont may be more susceptible to temperature stress, allowing growth of opportunistic microbial community members possibly detrimental to coral health.
\end{abstract}

KEY WORDS: Symbiodinium $\cdot$ Bacteria $\cdot$ Coral $\cdot$ Holobiont $\cdot$ Vibrio

\section{INTRODUCTION}

Reef-building corals host a variety of microorganisms, including symbiotic dinoflagellates called Symbiodinium (zooxanthellae) and an array of Bacteria, Archaea and viruses (reviewed in Knowlton \& Rohwer 2003). For decades, research on coral symbioses has focused on Symbiodinium and its photosynthesis, revealing the important roles that the algal endosymbiont plays in providing a source of carbon necessary for coral growth and in assisting calcification (Barnes \& Chalker 1990, Muller Parker \& D'Elia 1997). In contrast, the roles of bacterial and archaeal associates that populate the mucus and tissue layers of corals are poorly understood. Potential benefits for the coral holo- biont (which includes the host and all microbial partners) can be inferred from bacterial isolates and affiliated sequences retrieved from previous studies investigating coral-associated bacteria. Some coralassociated bacteria are known to fix nitrogen and carbon and may pass products to the coral host (Williams et al. 1987, Shashar et al. 1994, Cooney et al. 2002, Rohwer et al. 2002, Lesser et al. 2004). Other bacteria have been found to produce secondary metabolites such as antibiotics (Castillo et al. 2001). Moreover, bacteria isolated from the mucus of healthy Acropora palmata have been shown to inhibit growth of potentially pathogenic microbes (Ritchie 2006). Thus, bacterial communities may play important roles in maintaining coral health. 
Recently, the role and diversity of algal and bacterial symbionts, as well as the possibility that corals may adapt to environmental conditions by altering their symbiont communities (Buddemeier \& Fautin 1993, Reshef et al. 2006) have been the focus of a number of studies. It has been shown that different genetic types of Symbiodinium can differentially affect the physiology of the coral host. For example, corals containing Symbiodinium Clade D tend to be more tolerant to heat stress (Baker et al. 2004, Berkelmans \& van Oppen 2006), although species-specific coral-Symbiodinium interactions may modify this general pattern (Abrego et al. 2008). Furthermore, both Acropora tenuis and $A$. millepora juveniles grow 2 to 3 times faster when associating with Symbiodinium Clade C1 compared to those associated with Clade D (Little et al. 2004). Faster growth of corals infected with Symbiodinium C1 may reflect a greater contribution of the symbiont to host nutrition through faster rates of population growth inside the host (Fitt 1985) and/or doubling of the rate of photosynthate translocation to host tissues (Cantin et al. 2009). However, to date, no studies have investigated how different symbiotic Symbiodinium clades within the coral host might affect other microbial partners in the coral holobiont. As a multispecies mutualism, the relationship between corals and their symbionts may have an additional dimension; Symbiodinium endosymbionts may interact differentially with bacterial associates competing for space within the host to shape aspects of holobiont physiology. For instance, most (as high as $98 \%$ ) of the net carbon assimilated by Symbiodinium is released as exudates, much of it excreted into the mucus (Ikeda \& Miyachi 1995). Mucus composition is potentially important in structuring microbial communities (Ritchie \& Smith 2004). Ritchie \& Smith (1997) demonstrated that selective carbon source utilization by cultured bacteria differs among 11 coral species. Variation in photosynthetic contributions by different Symbiodinium could therefore affect the composition of coral mucus, indirectly impacting the coral microbiota. Changes in algal symbionts associated with corals may lead to differences in the bacterial populations on corals, and this may have larger implications in times of environmental stress, as changes in one component of the microbial community may cause a complete shift in coral-associated microbial communities.

To further our understanding of possible interactions between bacterial and Symbiodinium communities associated with coral, the present study compared the bacterial community profiles of 9 mo old juvenile colonies of the corals, Acropora millepora and $A$. tenuis, which had been experimentally infected with 2 different clades of Symbiodinium, C1 and D. Juvenile corals were raised from larvae to enable manipulation of the Symbiodinium type harboured upon initiation of symbiosis. Bacterial profiles of juvenile corals were compared to those of adult corals containing the same clade of Symbiodinium to determine if age affects the composition of bacterial communities. A second sample of A. tenuis juveniles (12 mo old) containing Clades $\mathrm{C} 1$ and D collected 3 mo later in summer was analysed to determine whether temporal changes, such as increase in temperature, might differentially influence bacterial communities associated with corals harbouring different Symbiodinium types. Three cultureindependent profiling methods were used to analyse bacterial associates: denaturing gradient gel electrophoresis (DGGE), clone library construction, and terminal restriction fragment length polymorphism (tRFLP) to cross-validate findings.

\section{MATERIALS AND METHODS}

Gamete collection, larval settlement and Symbiodinium infection. Juveniles of the corals Acropora tenuis and $A$. millepora were produced and experimentally infected with Symbiodinium C1 or D as described in Abrego et al. (2008). In brief, adult colonies of both species were collected from the upper reef slope in Nelly Bay, Magnetic Island $\left(19^{\circ} 10^{\prime} \mathrm{S}\right.$, $146^{\circ} 50^{\prime} \mathrm{E}$ ) just prior to spawning in November 2006 and placed in separate tanks onshore. Following spawning, gametes were collected from 4 colonies of each species and mixed in aquaria containing $1 \mu \mathrm{m}$ filtered seawater to effect fertilization. Once cleavage was detected, embryos were moved into larger culture tanks supplied with flow-through $1 \mu \mathrm{m}$ filtered seawater throughout larval development. When larvae commenced searching for settlement sites, sterilized terracotta tiles were placed on the bottom of culture tanks to provide settlement surfaces. Autoclaved coralline algae were then added to provide settlement cues for larvae. Following settlement, tiles were divided into separate tanks for infection with algal endosymbionts.

Settled Acropora tenuis and A. millepora corals were experimentally infected with both homologous and heterologous Symbiodinium clades. Algal isolates were prepared by airbrushing adult colonies of: (1) $A$. tenuis to collect Symbiodinium C1 and (2) A. millepora to collect Symbiodinium D. Colonies were collected from Magnetic Island, where these species are known to be associated with the targeted Symbiodinium clades (Little et al. 2004). Tissue slurries were centrifuged $(3000 \times g, 3 \mathrm{~min})$ to pellet Symbiodinium cells, and liquid was removed. Pellets were re-suspended in freshly filtered seawater and repeatedly washed until coral tissue was removed. Algal cells were counted under an Olympus BH-2 light microscope (Olympus Corp.) using a haemocytometer to determine concen- 
trations of cells. Isolates were diluted to approximately the same density of Symbiodinium cells (about 400 cells $\mathrm{ml}^{-1}$ ) and added in equal amounts into tanks containing settled larvae.

Following infection with the appropriate algal symbiont, colonies were sampled and the Symbiodinium clade was verified by single-stranded conformation polymorphism (SSCP). At the approximate size of 3 to 5 polyps, juvenile corals were returned to the parental habitat, where they remained until sampled. Tiles containing juvenile corals were placed on steel rods and suspended horizontally between pairs of metal starpickets on the reef flat in Nelly Bay, Magnetic Island.

Sample collection and processing. 9 mo (September 2007) and 12 mo (December 2007) after Acropora tenuis and $A$. millepora juveniles were out-planted to the reef, 6 juveniles containing Symbiodinium C1 and 6 containing Symbiodinium D from each coral species (i.e. 24 juveniles in total at each sample time) were removed from the settlement tiles by detaching colonies with a sterile scalpel (Table 1). Water temperatures were $25^{\circ} \mathrm{C}$ in September and reached $30^{\circ} \mathrm{C}$ in December. Whole juvenile colonies were rinsed with artificial seawater, placed in cryovials and stored at $-80^{\circ} \mathrm{C}$. The number of surviving juveniles was counted, and the size of each colony was measured at each sample time.

DNA extraction and purification. DNA was extracted by suspending an entire juvenile colony in $0.5 \mathrm{ml}$ of buffer (0.75 M sucrose, $40 \mathrm{mM}$ EDTA, $50 \mathrm{mM}$ Tris, pH 8.3) and following the extraction protocol outlined previously by Bourne et al. (2008). The DNA pellet was suspended in $30 \mu \mathrm{l}$ of sterile milli-Q water, and the total volume was loaded on a $1.2 \%$ low-melting agarose gel. DNA was purified by using electrophoresis and cutting high-quality DNA ( $>2 \mathrm{~kb}$ ) from the gel.

Table 1. Acropora millepora and A. tenuis. Sampling design and survey results. N: number of replicates; NA: not applicable

\begin{tabular}{|lcccc|}
\hline Age (mo) & $\begin{array}{c}\text { Symbiodinium } \\
\text { clade }\end{array}$ & $\mathrm{N}$ & $\begin{array}{c}\text { Size } \\
(\mathrm{cm})\end{array}$ & $\begin{array}{c}\text { Alive } \\
(\mathrm{n})\end{array}$ \\
\hline A. tenuis & $\mathrm{C} 1$ & 6 & $1-2$ & 126 \\
9 & $\mathrm{D}$ & 6 & $0.5-1$ & 81 \\
& $\mathrm{C} 1$ & 6 & $2-3$ & 112 \\
12 & $\mathrm{D}$ & 6 & 1 & 18 \\
& $\mathrm{C} 1$ & 3 & $\mathrm{NA}$ & $\mathrm{NA}$ \\
Adult & & & & \\
A. ${ }^{\mathrm{a}}$ millepora & $\mathrm{C} 1$ & 6 & $1-2$ & 123 \\
9 & $\mathrm{D}$ & 6 & $0.5-1$ & 63 \\
& $\mathrm{D}$ & 3 & $\mathrm{NA}$ & $\mathrm{NA}$ \\
Adult & $\mathrm{a}$ & & \\
${ }^{\mathrm{a}}$ Sample data from Littman et al. $(2009)$ & & \\
\hline
\end{tabular}

The agarose was then removed from the sample by using the QIAquick gel extraction kit (Qiagen), following the manufacturer's instructions. DNA was recovered from the Qiagen column with two $30 \mu$ l washes of sterile milli-Q water.

PCR amplification of the $16 \mathrm{~S}$ ribosomal RNA gene. Universal primers 63F and 1387R (Marchesi et al. 1998) were used to amplify the 16S rRNA genes from extracted DNA for bacterial clone library construction. Amplification of the 16S rRNA genes for tRFLP analysis was performed using the D4 labelled 63F primer and 1389R primer. The PCR mixtures $(50 \mu \mathrm{l})$ contained

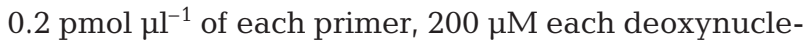
oside triphosphate, $1 \times \mathrm{PCR}$ buffer [Tris-Cl, $\mathrm{KCl}$, $\left.\left(\mathrm{NH}_{4}\right)_{2} \mathrm{SO}_{4}, 1.5 \mathrm{mM} \mathrm{MgCl} 2\right], 0.08 \%$ (w/v) bovine serum albumin and $1.25 \mathrm{U}$ of Taq polymerase (Scientifix). PCR was performed with an Applied Biosystems 2720 thermocycler and programmed with an initial $3 \mathrm{~min}$ step at $94^{\circ} \mathrm{C}$ and 35 cycles consisting of $94^{\circ} \mathrm{C}$ for $1 \mathrm{~min}$, $55^{\circ} \mathrm{C}$ for $1 \mathrm{~min}$ and $72^{\circ} \mathrm{C}$ for $1.5 \mathrm{~min}$ and a final extension for $10 \mathrm{~min}$ at $72^{\circ} \mathrm{C}$.

For DGGE, the bacterial 16S rRNA gene was amplified using primers $1055 \mathrm{~F}$ and 1392R-GC (Ferris et al. 1996). PCR reactions $(50 \mu \mathrm{l})$ consisted of $0.5 \mu \mathrm{M}$ of each primer, $100 \mu \mathrm{M}$ of each deoxyribonucleotide triphosphate, $0.08 \%(\mathrm{w} / \mathrm{v})$ bovine serum albumin, $1 \times \mathrm{PCR}$ buffer [Tris- $\mathrm{Cl}, \mathrm{KCl},\left(\mathrm{NH}_{4}\right)_{2} \mathrm{SO}_{4}, 1.5 \mathrm{mM} \mathrm{MgCl}{ }_{2}$, $1.5 \mathrm{mM} \mathrm{MgCl}_{2}$ and $1.25 \mathrm{U}$ of Hotstar Taq (Qiagen). DGGE PCR reactions were carried out using an Eppendorf Mastercycler thermocycler. Temperature cycling was performed using a touchdown protocol (Ferris et al. 1996) with 1 cycle of $95^{\circ} \mathrm{C}$ for $15 \mathrm{~min}$, 10 cycles of $94^{\circ} \mathrm{C}$ for $1 \mathrm{~min}, 53^{\circ} \mathrm{C}$ (each cycle decreasing by $1^{\circ} \mathrm{C}$ ) for $1 \mathrm{~min}$ and $72^{\circ} \mathrm{C}$ for $1 \mathrm{~min}$, followed by 20 cycles of $94^{\circ} \mathrm{C}$ for $1 \mathrm{~min}, 43^{\circ} \mathrm{C}$ for $1 \mathrm{~min}$ and $72^{\circ} \mathrm{C}$ for $1 \mathrm{~min}$.

SSCP. SSCP was used to identify the Symbiodinium type present in each juvenile at each sampling to ensure that corals still harboured the same C1 or D Symbiodinium type with which they were initially infected. The 18S internal transcribed spacer 1 (ITS1) region of Symbiodinium clades was amplified using ITSF and ITSR primers (van Oppen et al. 2001). PCR products were diluted 1:3 with formamide dye and denatured by placing them at $95^{\circ} \mathrm{C}$ for $5 \mathrm{~min}$ and then immediately on ice. Products were loaded on $4 \%$ acrylamide gel and run on a Gel-Scan 3000 (Corbett Robotics) with $0.5 \times$ TBE buffer $(0.01 \mathrm{M}$ Tris base, $0.01 \mathrm{M}$ boric acid and $0.2 \mathrm{mM} \mathrm{Na}_{2}$ EDTA; $\mathrm{pH}$ adjusted to 8.3$)$. Temperature was set at $22^{\circ} \mathrm{C}$ and run at $1200 \mathrm{~V}$ for $25 \mathrm{~min}$. Gels were imaged using Gel-Scan 3000 software (Corbett Robotics).

Clone library construction. The amplified bacterial DNA was ligated into TOPO-cloning vector following the manufacturer's instructions (Invitrogen). Ligations 
were submitted to the Australian Genome Research Facility for transformation, cloning and subsequent sequencing. Two replicate libraries of 96 clones each were sequenced for samples containing each Symbiodinium clade for both Acropora species. Dominant bacterial 16S rRNA gene sequences retrieved from each clone library were analysed using principal components analysis (PCA) to determine which sequences (affiliated at the genera level) were important in driving differences between the libraries. Due to the high amount of variability in each library, only $16 \mathrm{~S}$ rRNA gene sequences that constituted $2 \%$ or more of any clone library were included in the PCA analysis.

DGGE. Bacterial profiling was carried out using an INGENY phorU-2 (Ingeny International BV) DGGE system. PCR products were separated on gels containing $6.5 \%$ acrylamide with a 50 to $70 \%$ linear gradient of formamide and urea, using $0.5 \times$ TAE buffer $(0.02 \mathrm{M}$ Tris base, $0.01 \mathrm{M}$ sodium acetate and $0.5 \mathrm{mM} \mathrm{Na}_{2}$ EDTA; $\mathrm{pH}$ adjusted to 7.4). The buffer was preheated to $60^{\circ} \mathrm{C}$ prior to sample loading, and the electrophoresis was run at $30 \mathrm{~V}$ for 20 min to draw the DNA into the gel before running buffer through the system. Electrophoresis was then run at $60^{\circ} \mathrm{C}$ for $16 \mathrm{~h}$ at $70 \mathrm{~V}$. Gels were removed and stained for 10 min with SYBR Gold nucleic acid stain (Molecular Probes Inc.) in $1 \times$ TAE buffer. Gels were de-stained by rinsing with $1 \times$ TAE buffer and subsequently photographed using a transilluminator.

Clear bands were excised from the gel and placed in $100 \mu \mathrm{l}$ of sterile milli-Q water to elute DNA from the acrylamide gel. The DNA bands were re-amplified and run on the DGGE gel to ensure correct migration and purity of the product. Products that showed 1 distinct band with the correct mobility on the DGGE were directly sequenced. Using the sequences recovered from cut bands, a presence/absence matrix was constructed for the DGGE fingerprints and analysed by non-metric multi-dimensional scaling (nMDS) using Euclidian distances.

tRFLP. Prior to restriction digestion, 3 replicate PCR products for each sample were pooled and purified using the QIAquik PCR Purification Kit (Qiagen). The restriction reaction mix was prepared with $1 \times \mathrm{NEB}$ Buffer 4 (New England Biolabs), $1 \times$ BSA and $10 \mathrm{U}$ of Hha1 and added to $15 \mu$ of pooled PCR product. Samples were incubated at $37^{\circ} \mathrm{C}$ for $5 \mathrm{~h}$ and were subsequently heat inactivated for $20 \mathrm{~min}$ at $65^{\circ} \mathrm{C}$. The digested DNA was then precipitated from the solution by adding $2 \mu \mathrm{l}$ of $\mathrm{NaOAc}$ (pH 5.2) and $50 \mu \mathrm{l}$ of $95 \%$ icecold ethanol and centrifuged at $13000 \times g$ for $5 \mathrm{~min}$ at $4{ }^{\circ} \mathrm{C}$. The ethanol was removed, and the DNA was again washed with $100 \mu \mathrm{l}$ of $70 \%$ ethanol. All ethanol was removed from the sample and air dried until residual alcohol had evaporated. The DNA pellets were re- suspended in Beckman Coulter solutions (Beckman Coulter Inc.) containing $0.25 \mu \mathrm{l}$ of size standard (600 bp) and $39.75 \mu \mathrm{l}$ of SLS and were loaded onto a 96-well sample plate. Plates were centrifuged briefly at $500 \times g$, and each digest was then overlaid with 1 drop of mineral oil. Digested samples were separated on a Beckman Coulter CEQ 8800 sequencer. Fragment analysis was performed on an 8 capillary array in fragment analysis mode using Beckman Coulter CEQ 8000 software. The parameters included a modified Fragment 4 injection time of $20 \mathrm{~s}$, with a ramp to $2 \mathrm{kV}$ over $2 \mathrm{~min}$ and run at $4.9 \mathrm{kV}$ and $60^{\circ} \mathrm{C}$ for $60 \mathrm{~min}$. Peak size and retention times were exported into T-align (Smith et al. 2006), and consensus peaks were determined by aligning replicate peak profiles and including any peaks within a range of 0.5 peak area. Peak profiles were then converted into a presence/absence matrix and visualized using nMDS with Euclidean distances.

Sequence phylogenetic analysis and diversity indices. Sequences from clone libraries were checked for chimera formation with the CHECK_CHIMERA software of the Ribosomal Database Project (Maidak et al. 1996). Sequence data (approximately 700 bp each) were aligned to the closest relative using the BLAST database algorithm (Altschul et al. 1997), and all sequence affiliations were determined by $>97 \%$ identity to bacterial 16S rRNA gene sequences in the GenBank database. Sequence affiliations were cross-validated with the Greengenes database (http://greengenes. lbl.gov) (DeSantis et al. 2006) using the Hugenholtz and Ribosomal Database Project (RDP) (Maidak et al. 1996) alignments, and sequences that closely affiliated with uncultured bacteria were assigned taxonomic affiliations using RDP database alignments. Sequences were assigned operational taxonomic units (OTUs) by comparing sequences with the same affiliations and grouping those with $>97 \%$ similarity. The OTUs of library clone and DGGE sequences were imported into the ARB software package (www.arb-home.de) (Ludwig et al. 2004), aligned against the Greengenes database (http://greengenes.lbl.gov) (DeSantis et al. 2006) that is compatible with ARB and subject to manual correction of the alignment when necessary. OTUs that were $>2 \%$ of any juvenile clone library were included in a phylogenetic tree with dominant bacterial sequences retrieved from adult samples (Littman et al. 2009) to determine which conserved adult bacteria are present in juvenile samples. DGGE sequences were also included in the tree to determine sequence affiliations as well as crossvalidate sequence alignments with clone library data. Tree topologies were evaluated by reconstructing phylogenies using evolutionary distance (Phylip distance method with the Jukes and Cantor model) analysis of aligned near full-length sequences (>1000 bp) (Ludwig et al. 1998). Ambiguous 
sequence regions were removed from the analysis. Aligned, partial 16S rRNA gene sequences (<1000 bp) were subsequently inserted without changing the overall tree topology using the parsimony tool available within ARB. The nucleotide sequence data of clones and DGGE sequences appear in the GenBank nucleotide database under the Accession Numbers GQ301209 to GQ301527.

Diversity indices were compared for adult and juvenile Acropora millepora and A. tenuis containing the same Symbiodinium clades. The Shannon-Weaver diversity index (Shannon \& Weaver 1963), the Chao1 richness estimator (Chao 1987) and Fisher's Alpha log series richness index (Fisher et al. 1943) were calculated using the freeware program EstimateS Win 7.52 (Colwell 2006). Coverage values were calculated by the equation: $C=1-(n / N) \times 100$, where $n$ is the number of unique clones and $N$ is the total number of clones examined in the libraries (Good 1953). The diversity of clone libraries was further investigated by rarefaction analysis (Hurlbert 1971, Heck et al. 1975, Simberloff 1978). Rarefaction curves were produced by using the analytical approximation algorithm of Hurlbert (1971). Calculations were performed with the freeware program aRarefact Win (Holland 1988).

\section{RESULTS}

\section{Bacterial community profiles of 9 mo old juveniles}

A total of 81 Acropora tenuis juveniles from the Symbiodinium D treatment and 126 from the Symbiodinium $\mathrm{C} 1$ treatment were alive when surveyed after 9 mo (September 2007). On average, D juveniles contained $23 \pm 4$ polyps and were ( 0.5 to $1 \mathrm{~cm}$ in diameter), in contrast to $\mathrm{C} 1$ juveniles, which contained approximately $51 \pm 9$ polyps and were visibly larger (1 to $2 \mathrm{~cm}$ ). For A. millepora, 63 juveniles from the D treatment and 123 juveniles from the $\mathrm{C} 1$ treatment were alive at the time of the September sample. Average polyp counts (D juveniles: $18 \pm 5 ; \mathrm{C} 1$ juveniles: $50 \pm 8$ ) and colony sizes (D juveniles: 0.5 to $1.0 \mathrm{~cm}$; $\mathrm{C} 1$ juveniles: 1 to $2 \mathrm{~cm}$ ) of the A. millepora juveniles were similar to those of $A$. tenuis juveniles from the respective Symbiodinium C1 and D treatments (Table 1).

Bacterial communities identified within 16S rRNA gene clone libraries of all 9 mo old coral juveniles were dominated by $\alpha$ - and $\gamma$-Proteobacteria-affiliated sequences. No differences in dominant phylogenetic groups at the class level were discernable among corals containing different Symbiodinium clades (Table S1, available in the electronic supplement at www.int-res.com/articles/suppl/m389p045_app.pdf). Retrieved sequence diversity within the libraries ex- amined at the genus and family levels demonstrated high bacterial diversity, and there were few similarities between coral juveniles, either when compared between Acropora tenuis and A. millepora juveniles associated with the same Symbiodinium type, or when compared between $\mathrm{C} 1$ and D juveniles within a species. Each juvenile clone library correlated with different dominant bacteria genera; there were also few similarities between any of the bacterial communities associated with the replicate juveniles within each coral species (Table 2). However, a few bacterial sequence OTUs appeared within replicate libraries more frequently, suggesting that juvenile libraries may have limited structure. The sequences that were recovered from multiple libraries, from both $A$. millepora and $A$. tenuis libraries hosting both Symbiodinium Clades C1 and D, include OTU-007 (affiliated with Flavobacteria sp.), OTU-009 (related to Muricauda sp.), OTU-168 (related to Roseobacter sp.), OTU-290 (related to Achromobacter sp.), OTU-308 (related to Pseudomonas sp.) and OTU-310 (affiliated to Serratia sp.). Two OTUs (148 and 149) related to Brevundimonas sp. appeared within most libraries, while a Stenotrophomonas sp.related sequence (OTU-314) represented a large component of each library (between 2.2 and $31.7 \%$ of clones). Nevertheless, most common sequences listed above do not appear in every library and vary drastically in their relative proportions (Table 2). In addition, all juvenile clone libraries possessed a large number of independent bacterial ribotypes that only appeared once in each library, which is represented by the large number of OTU groups identified (Table S1). Due to the high variability and diversity within all juvenile libraries, no consistent patterns could be detected between samples harbouring Clade C1 or D Symbiodinium by directly comparing relative abundances of retrieved 16S rRNA gene sequences.

Bacterial community profiles assessed by DGGE displayed variable and complex banding patterns for replicate samples of both coral species. Sequences recovered from replicate DGGE sample profiles affiliated with Brevundimonas sp., Stenotrophomonas sp., Muricauda sp., Achromobacter sp. and Ruegeria sp. and corresponded to sequences retrieved from many Acropora tenuis and A. millepora clone library sequences (Table 2). This confirms that some bacterial ribotypes were consistent despite high diversity and variability in bacterial profiles. The nMDS plots representative of DGGE profiles for colonies of both A. tenuis (Fig. 1A) and A. millepora (Fig. 1B) show limited grouping of samples containing each of the 2 Symbiodinium clades, indicating that, as suggested by the clone library data, there was no obvious relationship between the clade of Symbiodinium harboured and the bacterial community composition in 
juveniles of these 2 corals. Bacterial diversity fingerprints generated from tRFLP peak patterns were consistent with both clone library and DGGE analysis in showing no strong grouping or consistency in peak patterns for replicate juvenile samples (Fig. 1C,D). While nMDS representation of tRFLP peak patterns displayed some grouping of $A$. tenuis juveniles containing Clade D Symbiodinium (Fig. 1C), other repli- cate samples were dispersed. C1 juveniles, in particular, displayed little consistency in this species. A. millepora juveniles (Fig. 1D) differed between replicate samples possessing the same clade, for those associated both with Symbiodinium C1 and D (Fig. 1D), again indicating no clear relationship between the Symbiodinium type harboured and the bacterial community composition.

Table 2. Proportions of dominant operational taxonomic units (OTU) retrieved from 16S rRNA gene juvenile clone libraries (\%). Sequences included comprise $>2 \%$ of any juvenile clone library; sequences were aligned to the closest relative using BLAST (Altschul et al. 1997). The similarity was calculated without taking gaps into account. MC: A. millepora hosting Clade C1; MD: A. millepora hosting Clade D; TC: A. tenuis hosting Clade C1; TD: A. tenuis hosting Clade D; S-TC: A. tenuis hosting Clade C1 sampled in summer; S-TD: A. tenuis hosting Clade C1 sampled in summer; Unc.: unclassified

\begin{tabular}{|c|c|c|c|c|c|c|c|c|c|c|c|c|c|c|c|}
\hline Clone & Closest relative & Identity & ty Affiliation & MC1 & $\mathrm{MC} 2$ & MD1 & MD2 & $\mathrm{TC} 1$ & $\mathrm{TC} 2$ & TD1 & TD2 & S-TC1 & $\mathrm{S}-\mathrm{TC} 2$ & S-TD1 & S-TD2 \\
\hline OTU-001 & Acidobacteria (DQ289940) & 98 & Acidobacteria & & & & & & 2.4 & 1.2 & & & & & \\
\hline OTU-004 & Bacteroidetes bacterium (AY162097) & 7) 99 & Bacteroidetes & & & 1.2 & 1.1 & 2.4 & 3.5 & & & & & & \\
\hline OTU-007 & Flavobacteria (AF277542) & 98 & Bacteroidetes & 4.3 & & 1.2 & 2.3 & 1.2 & 1.2 & 1.2 & & 8.3 & 5.3 & & \\
\hline OTU-009 & Muricauda sp. (AY576744) & 99 & Bacteroidetes & 2.2 & & 1.2 & & 2.4 & & & & 2.1 & 2.6 & & \\
\hline OTU-015 & Lyngbya sp. (AB045906) & 93 & Cyanobacteria & 3.2 & & & & & & & & & & & \\
\hline OTU-016 & Oscillatoria sp. (AB058224) & 96 & Cyanobacteria & 1.1 & & 2.4 & 2.3 & & & & & & & & \\
\hline OTU-020 & Synechococcus sp. (AF132772) & 91 & Cyanobacteria & 4.3 & & & & & & & & & & & \\
\hline OTU-023 & Unc. bacterium (AF424415) & 95 & Firmicutes & 1.1 & & 2.4 & & & & & & & & & \\
\hline OTU-024 & Unc. bacterium (AY258098) & 97 & $\alpha$-Proteobacteria & 1.1 & & 2.4 & & & & & & & & & \\
\hline OTU-058 & Unc. bacterium (AY942776) & 97 & $\alpha$-Proteobacteria & & & 2.4 & 5.7 & & & & & & & & \\
\hline OTU-064 & Unc. bacterium (AY568808) & 95 & $\delta$-Proteobacteria & & & & 4.5 & & & & & & & & \\
\hline OTU-011 & Unc. bacterium (EF378470) & 97 & Bacteroidetes & & & & & 1.2 & & & & 6.3 & 1.3 & & \\
\hline OTU-144 & Agrobacterium sp. (AB247617) & 99 & $\alpha$-Proteobacteria & 2.2 & & & 1.1 & & & 1.2 & & & & & \\
\hline OTU-148 & Brevundimonas sp. (AB426561) & 99 & $\alpha$-Proteobacteria & & & & 1.1 & 13.4 & 1.2 & 25.9 & 21.1 & 10.4 & 2.6 & 1.4 & 3.1 \\
\hline OTU149 & Caulobacteraceae (DQ857204) & 99 & $\alpha$-Proteobacteria & 2.2 & 2.3 & & & & 4.7 & & 7.8 & & & & \\
\hline OTU-150 & Erythrobacter sp. (DQ985055) & 98 & $\alpha$-Proteobacteria & & 4.7 & 2.4 & & & & & & & & & 3.1 \\
\hline OTU-153 & Kordiimonas sp. (AY682384) & 93 & $\alpha$-Proteobacteria & 1.1 & & & & & 2.4 & & & & & & \\
\hline OTU-155 & Mesorhizobium sp. (DQ917826) & 98 & $\alpha$-Proteobacteria & & & & 3.4 & & & & & & & & 6.3 \\
\hline OTU-161 & Rhodobacteraceae (AY962292) & 99 & $\alpha$-Proteobacteria & 4.3 & & & & & 1.2 & & & & & & \\
\hline OTU-165 & Rhodopseudomonas sp. (AY428572) & 2) 93 & $\alpha$-Proteobacteria & & & & 4.5 & & & & & & & & \\
\hline OTU-168 & Roseobacter sp. (AY745856) & 99 & $\alpha$-Proteobacteria & & & & & 1.2 & 1.2 & 3.5 & 3.3 & & 5.3 & 4.2 & \\
\hline OTU-170 & Ruegeria sp. (AJ391197) & 99 & $\alpha$-Proteobacteria & & & & 3.4 & & 1.2 & & & & & 6.9 & \\
\hline OTU-171 & Silicibacter sp. (AY369990) & 99 & $\alpha$-Proteobacteria & 1.1 & & & 3.4 & & & & & & & 1.4 & \\
\hline OTU-173 & Sphingomonas sp. (EU817494) & 99 & $\alpha$-Proteobacteria & & & & & & & & & 8.3 & 2.6 & & 3.1 \\
\hline OTU-177 & Unc. $\alpha$-Proteobacterium (AY499896) & 6) 95 & $\alpha$-Proteobacteria & 6.5 & & & 1.1 & & & & & & & & \\
\hline OTU-184 & Unc. $\alpha$-Proteobacterium (AJ890099) & 9) 99 & $\alpha$-Proteobacteria & 3.2 & & 1.2 & & & & & & & & & \\
\hline OTU-191 & Unc. $\alpha$-Proteobacterium (AJ633940) & ) 99 & $\alpha$-Proteobacteria & & & 7.2 & & & & & & & & & \\
\hline OTU-202 & Unc. $\alpha$-Proteobacterium (AM162572 & 2) 89 & $\alpha$-Proteobacteria & & & & 3.4 & & & & & & & & \\
\hline OTU-218 & Unc. $\alpha$-Proteobacterium (DQ107390) & 0) 99 & $\alpha$-Proteobacteria & & & & & 1.2 & 2.4 & & & & & & \\
\hline OTU-262 & Unc. $\alpha$-Proteobacterium (DQ003179) & 9) 99 & $\alpha$-Proteobacteria & & & & & & & 3.5 & & & & & \\
\hline OTU-279 & Mucus bacterium (AY654746) & 99 & $\alpha$-Proteobacteria & 5.4 & & 4.8 & & & & & & & & & \\
\hline OTU-290 & Achromobacter sp. (EU275167) & 100 & $\beta$-Proteobacteria & & 7.0 & 1.2 & & & & 8.2 & 2.2 & & & & \\
\hline OTU-291 & Delftia sp. (EU019989) & 99 & $\beta$-Proteobacteria & & & & & & & 3.5 & & & & & \\
\hline OTU-294 & Unc. $\beta$-Proteobacterium (EF061949) & ) 99 & $\beta$-Proteobacteria & & & 3.6 & & & & & & & & & \\
\hline OTU-293 & Unc. $\beta$-Proteobacterium (AB288554) & 4) 99 & $\beta$-Proteobacteria & 1.1 & & & & & & 3.5 & & & & & \\
\hline OTU-299 & Alteromonas sp. (EU529840) & 100 & $\gamma$-Proteobacteria & 3.2 & & & & & & & & 2.1 & & 1.4 & \\
\hline OTU-300 & Escherichia sp. (AM087500) & 99 & $\gamma$-Proteobacteria & & & 1.2 & & & & & 1.1 & 4.2 & & & 3.1 \\
\hline OTU-308 & Pseudomonas sp. (AY014801) & 99 & $\gamma$-Proteobacteria & & & 3.6 & 3.4 & 1.2 & & 1.2 & & 2.1 & & 6.9 & \\
\hline OTU-310 & Serratia sp. (AY566180) & 99 & $\gamma$-Proteobacteria & & & 1.2 & 3.4 & & & 1.2 & 2.2 & & & & \\
\hline OTU-313 & Spongiobacter sp. (AB205011) & 98 & $\gamma$-Proteobacteria & & & 1.2 & & 2.4 & & 1.2 & 1.1 & & & & \\
\hline OTU-314 & Stenotrophomonas sp. (AM402950) & 100 & $\gamma$-Proteobacteria & 2.2 & 27.9 & 8.4 & 4.5 & 31.7 & 8.2 & 29.4 & 24.4 & & & 2.8 & \\
\hline OTU-315 & Thalassomonas sp. (AY194066) & 98 & $\gamma$-Proteobacteria & 9.7 & & & 1.1 & & 1.2 & & & & & & \\
\hline OTU-348 & Vibrio sp. (AJ316167) & 99 & $\gamma$-Proteobacteria & & & & & & & & & & & 13.9 & \\
\hline OTU-349 & Unc. $\alpha$-proteobacterium (DQ146982) & 2) 99 & $\gamma$-Proteobacteria & 5.4 & & & 1.1 & & & & 1.1 & & & & \\
\hline OTU-350 & Vibrio sp. (EU372927) & 99 & $\alpha$-Proteobacteria & & & & & & & & & & & & 18.8 \\
\hline OTU-355 & Haliangium sp. (AB062751) & 97 & $\delta$-Proteobacteria & & & 3.6 & & & & & & & & & \\
\hline OTU-356 & Myxobacterium (AB016469) & 97 & $\delta$-Proteobacteria & & & 1.2 & & & 2.4 & & & & & & \\
\hline
\end{tabular}



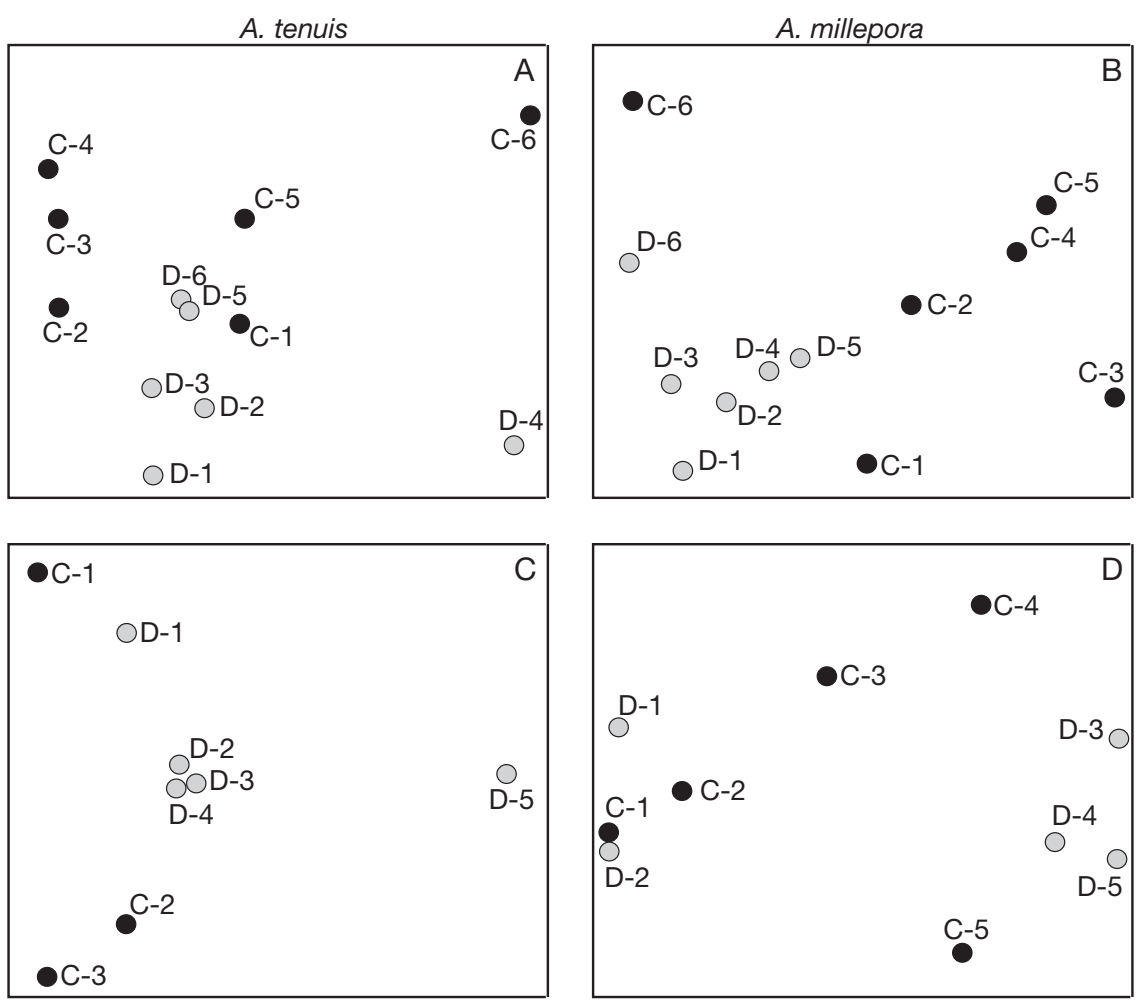

Fig. 1. Acropora tenuis and A. millepora. Comparison of 9 mo old juvenile corals containing Clade C1 and D Symbiodinium by non-metric multidimensional scaling (nMDS) of bacterial profiles. Denaturing gradient gel electrophoresis (DGGE) profiles of (A) A. tenuis and (B) A. millepora. Terminal restriction fragment length polymorphism (tRFLP) profiles of (C) A. tenuis and (D) A. millepora. Several replicate samples are missing in the tRFP analysis such as D-6, C-4, C-5 and C-6 for A. tenuis and C-6 for A. millepora, due to poor reads by the sequencer and resulting loss of DNA after repeated trials, which may contribute to the lack of pattern observed in the plot

\section{9 mo old juvenile versus adult bacterial communities}

Diversity parameters associated with clone libraries generated from the 9 mo old juvenile samples were compared with bacterial diversities of adult corals associated with the corresponding Symbiodinium clades and collected from the same sites (Littman et al. 2009). Only clone libraries of 9 mo old corals with the same Symbiodinium clade to those of the adult libraries were included in the analysis, such as Acropora millepora harbouring Clade D and $A$. tenuis hosting Clade C1, to eliminate symbiont type as a possible influence. A total of 141 OTUs (grouped at $97 \%$ sequence identity) were identified within A. millepora juvenile coral libraries compared to only 53 OTUs from libraries of adult corals (Table 3). For both juvenile and adult A. millepora samples, libraries were pooled for the analysis, resulting in a total of 187 clones included in each analysis. For $A$. tenuis, 107 OTUs were identified within pooled juvenile libraries compared to 49 OTUs for adult $A$. tenuis (out of 179 and 183 clones, respectively). Many sequences retrieved from juveniles affiliated with previously unclassified sequences and were the sole ribotypes within a defined OTU. Other bacterial ribotype richness (Chao1 and the Fisher abundance model) and evenness (Shannon-Weaver index) indices supported

Table 3. Acropora millepora and A. tenuis. Diversity indices calculated from operational taxonomic units (OTUs) $(97 \%$ similarity) of $16 \mathrm{~S}$ rRNA clone libraries. Clones: no. of clones analysed; coverage: coverage of clone libraries; OTU: observed no. of OTUs; $H^{\prime}$ : Shannon-Weaver diversity index; Chao1: Chao's richness estimator; $\alpha$ : Fisher's alpha; $D$ : Simpson's evenness

\begin{tabular}{|c|c|c|c|c|c|c|c|}
\hline & $\begin{array}{l}\text { Clones } \\
\text { (n) }\end{array}$ & $\begin{array}{c}\text { Coverage } \\
(\%)\end{array}$ & $\begin{array}{l}\text { OTU } \\
\text { (n) }\end{array}$ & $H^{\prime}$ & Chao1 & $\alpha$ & $D$ \\
\hline \multicolumn{8}{|c|}{ A. millepora } \\
\hline Adult & 187 & 71.7 & 53 & 3.4 & 80.2 & 24.7 & 21.74 \\
\hline Juvenile & 187 & 24.6 & 141 & 4.8 & 474.2 & 260.9 & 238.2 \\
\hline \multicolumn{8}{|l|}{ A. tenuis } \\
\hline Adult & 183 & 73.2 & 49 & 3.3 & 72.2 & 21.9 & 19.7 \\
\hline Juvenile & 179 & 43.0 & 102 & 4.2 & 280.3 & 98.4 & 50.1 \\
\hline
\end{tabular}




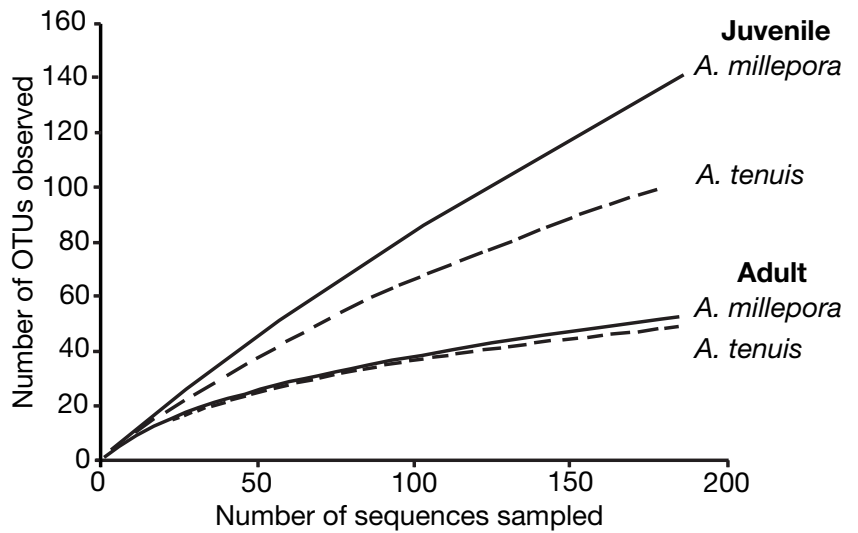

Fig. 2. Acropora millepora and A. tenuis. Rarefaction analysis of adult and 9 mo old juvenile A. millepora and A. tenuis. A. millepora corals compared harbour Clade $\mathrm{D}$, while A. tenuis corals contain Clade C1 Symbiodinium. OTUs: operational taxonomic units

the conclusion that diversity was higher within juvenile samples (Table 3 ). The obtained sequences covered a high percentage of the diversity in the adult libraries (72 and $73 \%$ for A. millepora and A. tenuis libraries, respectively) in comparison to juvenile libraries (25 and $43 \%$ for A. millepora and A. tenuis libraries, respectively). Rarefaction curves confirmed the coverage calculations, with juvenile libraries failing to reach an asymptote in comparison to curves for adult corals (Fig. 2). Although greater numbers of sampled clones would better represent bacterial diversity for all libraries, it was apparent that bacterial diversity of juvenile corals was vastly undersampled compared to that of adult corals.

nMDS representation and direct comparisons of juvenile and adult coral bacterial DGGE profiles displayed tight grouping of bacterial fingerprints for adult corals of both Acropora tenuis (Fig. 3A) and A. millepora (Fig. 3B). Noticeably, the juvenile samples were widely spaced within the nMDS representation of DGGE fingerprints, indicating high variability in profiles in comparison to adult profiles. Similarly, nMDS plots of tRFLP profiles showed much tighter grouping of adult coral samples relative to juvenile sample profiles for both species (Fig. 3C,D).

Most sequences from adult Acropora millepora and A. tenuis clones libraries were closely related to sequences retrieved from juvenile libraries. For example, phylogenetic analysis of dominant OTUs from juvenile libraries including OTUs 148 and 149 related to Brevundimonas sp., 313 related to Spongiobacter sp., 314 related to Stenotrophomonas sp., 168 related to Roseobacter sp.
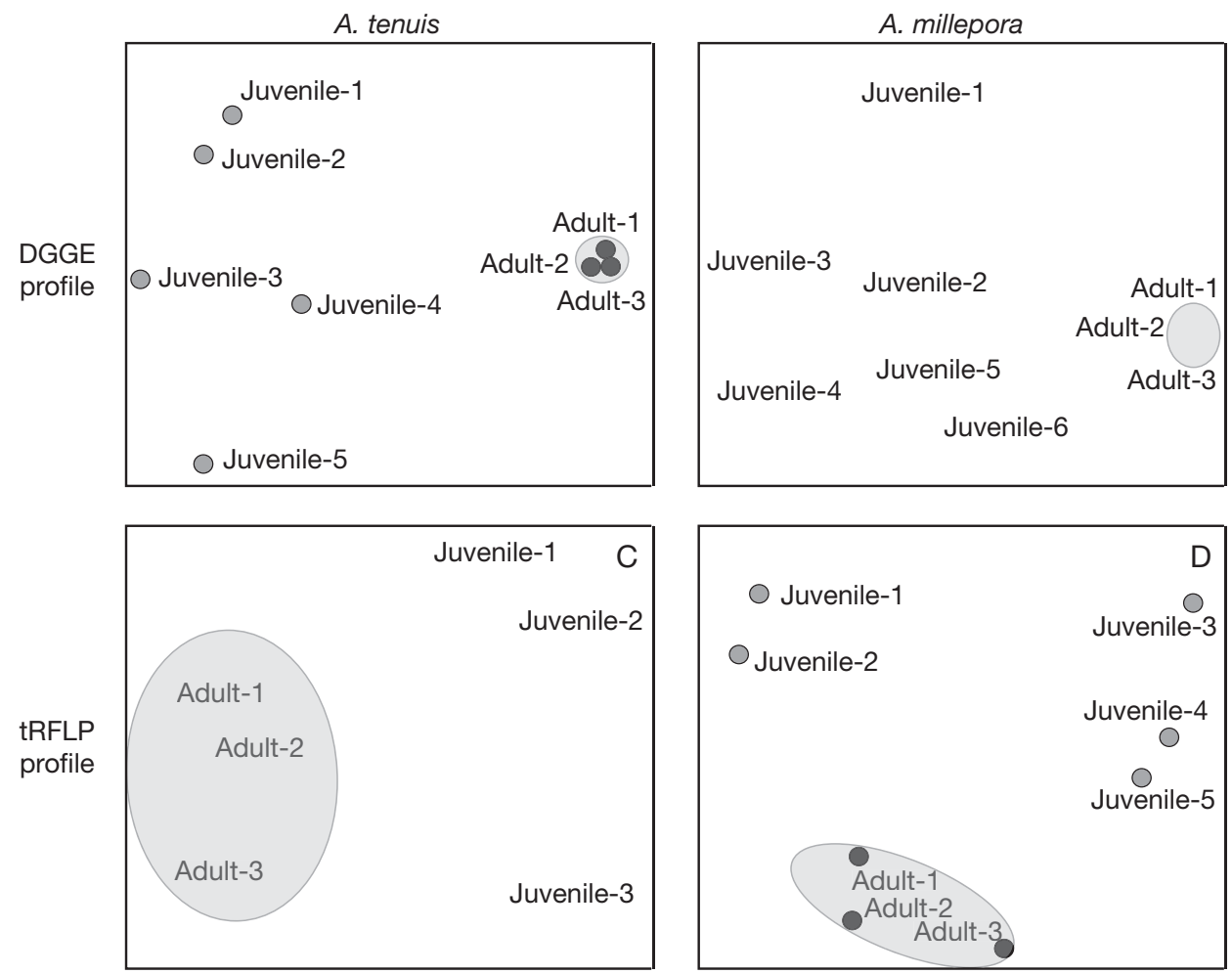

Fig. 3. Acropora millepora and A. tenuis. Comparison of 9 mo old juvenile and adult corals by nMDS of bacterial profiles. DGGE profiles of (A) A. tenuis and (B) A. millepora. Terminal restriction fragment length polymorphism (tRFLP) profiles of (C) A. tenuis and (D) A. millepora 
and 161 of the Rhodobacter group all correspond to dominant sequences retrieved from adult clone libraries (Fig. S1, available at www.int-res.com/articles/suppl/ m389p045_app.pdf). Therefore, despite the high diversity and variability within juvenile libraries, many of the adult sequences are present in varying relative proportions, although not consistently detected in all libraries (Table 2). Also, a few dominant sequences found on adult corals were not retrieved from juvenile samples, including the $\delta$ Proteobacterium (FJ489722), Anaeromyxobacteria-related sequence (FJFJ489711) and Marinobacter-related sequence (FJ489730).

\section{Temporal changes in bacterial communities of Acropora tenuis}

Survival of juvenile colonies of $A$. tenuis was reduced after 12 mo (December 2007; Austral summer) when water temperatures reached $30^{\circ} \mathrm{C}$. At this sampling date, only 18 individuals (22\%) from the Symbiodinium $\mathrm{D}$ treatment remained alive, compared to 81 colonies when sampled 3 mo earlier. Colonies from the
Symbiodinium D treatment exhibited little growth, and average colony size remained at approximately 20 polyps (about $1 \mathrm{~cm}$ in diameter). In contrast, survival of A. tenuis from the Symbiodinium C1 treatment was 4 -fold greater (112 colonies or $89 \%$ remained alive) and colonies were noticeably larger in size (approximately 2 to $3 \mathrm{~cm}$ ) (Table 1 ).

Clone libraries of $1 \mathrm{yr}$ old Acropora tenuis juveniles infected with different clades of Symbiodinium displayed similar proportions of bacterial classes, although a greater proportion of $\gamma$-Proteobacteria affiliated sequences were recovered from $A$. tenuis hosting Clade D (33 and $34 \%$ of the sequences, respectively) in comparison to libraries of $A$. tenuis hosting Clade C1 (11 and 17\%, respectively). Bacterial profiles derived from clone libraries were analysed at the genus and family levels using PCA. The dominant ribotypes (grouped at $97 \%$ sequence identity) included in the PCA comprised $>2 \%$ of any library compared and accounted for $88 \%$ of the variability (Fig. 4). The PCA results for $1 \mathrm{yr}$ old $A$. tenuis revealed 1 distinct difference between samples hosting Clade D and C1 Symbiodinium. For both $A$. tenuis libraries contain-

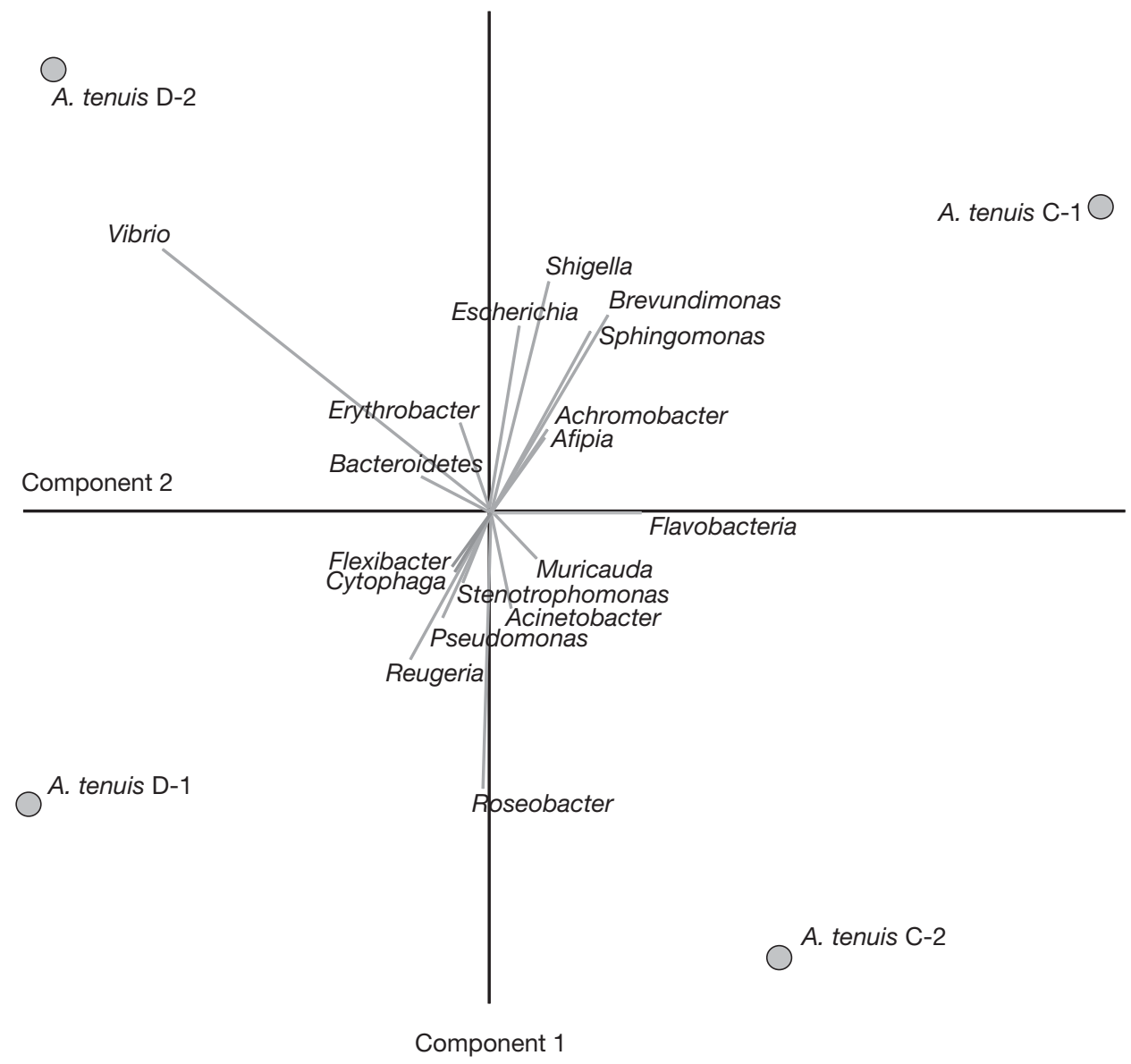

Fig. 4. Acropora tenuis. Principal components analysis of 1 yr old juveniles harbouring Clade C1 and D Symbiodinium 
ing Clade D, the sequences OTU-348 and -350, affiliating with Vibrio sp., were the dominant bacterial ribotype retrieved and were displayed as a prominent vector on the PCA plot. However, less dominant sequences within the libraries separated the $2 \mathrm{~A}$. tenuis Clade D libraries on the PCA plot. The sequences retrieved from A. tenuis Clade D Library 1 affiliated with Vibrio sp. (13.9\% of the library), Pseudomonas sp. ( $6.9 \%$ of the library), Ruegeria sp. (6.9\% of the library) and Roseobacter sp. (4.2\% of the library), while the dominant sequences retrieved from $A$. tenuis Clade D Library 2 affiliated with Vibrio sp. $(18.8 \%$ of the library) and other Bacteroidetes (6.3\% of the library) (Table 2). In contrast, no sequences affiliated with Vibrio $\mathrm{sp}$. were retrieved from the $A$. tenuis libraries that contained Clade C1 Symbiodinium. Variation within the dominant retrieved sequences of Clade C1 corals also caused separation of libraries on the PCA plot. Dominant sequences within the $A$. tenuis Clade $\mathrm{C} 1$ library affiliated with Brevundimonas sp. (10.4\% of the clone library), Flavobacteria sp. (8.3\% of the library), Shigella sp. (6.3\% of the library) and Sphingomonas sp. (8.3\% of the library), whereas the sequences that were most prevalent in the $A$. tenuis Clade $\mathrm{C} 2$ library affiliated with Flavobacteria (5.3\% of the library) and Roseobacter sp. (5.3\% of the library) (Table 2). The Vibrio sp. affiliated sequences within the Clade D A. tenuis libraries accounted for the 2- to 3-fold increase in the proportion of $\gamma$-Proteobacteria-affiliated clones within these libraries compared to the Clade D A. tenuis libraries. The Vibrio-like sequences OTU-348 and -350 were closely related $(99 \%$ identity) to the known coral pathogens Vibrio coralliilyticus (AJ316167) and Vibrio sp. (AJ316170) isolated from white syndrome (Fig. S1).

Distinctly different DGGE bacterial banding patterns were observed for replicate $1 \mathrm{yr}$ old samples of Acro- pora tenuis corals infected with D versus C1 Symbiodinium (Fig. 5A). nMDS representation of these DGGE profiles demonstrated grouping of Clade D corals (Fig. 5B). The dominant band (Fig. 5A; Band K) within Clade D profiles was related to Vibrio species, including a Vibrio sp. (98\% sequence identity) isolated from white syndrome (EU372927) (Table 4, Fig. S1), confirming observations that Vibrio spp. comprised a large component of the 1 yr old juvenile clone libraries harbouring Clade D. Interestingly the $1 \mathrm{yr}$ old juveniles hosting Clade $\mathrm{C} 1$ also appeared to have profiles that were consistent between replicate samples, with Bands A to $\mathrm{J}$ (Table 4) present in all profiles (Fig. 5A). This was in contrast to the profiles of 9 mo old juveniles that lacked consistent dominant microbial associations.

\section{DISCUSSION}

\section{Juvenile corals lack conserved microbial associates}

Coral microbial investigations over the last decade have highlighted the important role that the host's microbial partners, including photosynthetic Symbiodinium (zooxanthellae) and associated bacterial, fungal and archaeal microbiota, play in coral health (Knowlton \& Rohwer 2003). These studies have suggested that some adult corals conserve their bacterial partners, based on evidence that these corals harbour species-specific bacterial communities (Rohwer et al. 2001, 2002). More recently, it has been shown that, in some coral species, bacterial associations vary between reef locations (Littman et al. 2009), and the current study demonstrates that juvenile hosts do not establish the conserved microbial patterns characteristic of adult corals at early development stages. Support for this latter conclusion was based on the absence of
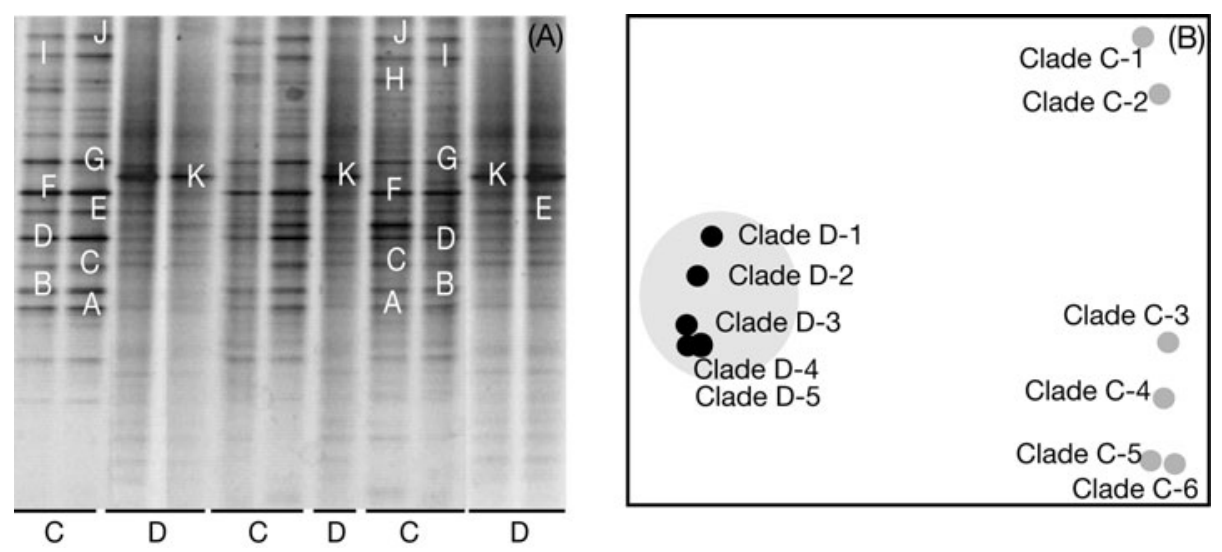

Fig. 5. Acropora tenuis. DGGE profiles for $1 \mathrm{yr}$ old A. tenuis harbouring Clade C1 and D Symbiodinium. (A) DGGE gel of samples containing different clades. Bands labelled A to K. (B) nMDS plot of DGGE profiles 
Table 4. Acropora tenuis. Affiliation of DGGE bacterial sequences retrieved from $1 \mathrm{yr}$ old juvenile coral colonies $(\mathrm{n}=11)$. Sequences were aligned to the closest relative using BLAST (Altschul et al. 1997). The similarity was calculated without taking gaps into account

\begin{tabular}{|c|c|c|c|c|}
\hline Band & Closest relative and database accession number & Alignment (bp) & Similarity (\%) & Taxonomic description \\
\hline A & Uncultured bacterium (DQ684483) & $241 / 304$ & 79 & $\gamma$-Proteobacteria ${ }^{a}$ \\
\hline B & Uncultured bacterium (EU808101) & $292 / 294$ & 99 & $\alpha$-Proteobacteria ${ }^{\mathrm{a}}$ \\
\hline $\mathrm{C}$ & Sphingobium sp. (EU679660) & $270 / 295$ & 91 & $\alpha$-Proteobacteria \\
\hline $\mathrm{D}$ & Uncultured bacterium (EU172379) & $300 / 303$ & 99 & $\beta$-Proteobacteria ${ }^{\mathrm{a}}$ \\
\hline $\mathrm{E}$ & Uncultured bacterium (EU535510) & $270 / 309$ & 87 & $\beta$-Proteobacteria ${ }^{\mathrm{a}}$ \\
\hline $\mathrm{F}$ & Achromobacter xylosoxidans (EU877076) & $274 / 285$ & 96 & $\beta$-Proteobacteria \\
\hline G & Alcaligenes sp. (EU304282) & $300 / 303$ & 99 & $\beta$-Proteobacteria \\
\hline $\mathrm{H}$ & Uncultured bacterium (EU010191) & $287 / 315$ & 91 & \\
\hline I & Flavobacterium frigidarium (AY771738) & $304 / 309$ & 98 & Bacteroidetes \\
\hline $\mathrm{J}$ & Flavobacterium frigidarium (AY771738) & $298 / 308$ & 96 & Bacteroidetes \\
\hline $\mathrm{K}$ & Vibrio sp. (EU372935) & $307 / 311$ & 98 & $\gamma$-Proteobacteria \\
\hline
\end{tabular}

conserved patterns in bacterial communities using bacterial 16S rRNA gene profiles from colonies of 9 mo old Acropora tenuis and A. millepora and 3 independent community profiling methods (clone libraries, DGGE and tRFLP analyses). Comparisons with a previous study of adults of the same coral species associated with the same Symbiodinium clades (Littman et al. 2009) highlight differences between juvenile and adult profiles, notably the highly conserved microbial profiles observed in adult corals using all three 16S rRNA gene profiling methods. Clone libraries of adults displayed lower relative diversity compared to juveniles, as determined by both diversity indices and rarefaction analysis, while nMDS interpretations of DGGE and t RFLP profiles displayed tight grouping of adult coral profiles in contrast to no apparent relationship among juvenile coral profiles.

Results from the present study also indicate that juvenile corals at 9 mo of age do not show any discernable relationship between the Symbiodinium clade present in the coral host and the bacterial community structure. Previous research has demonstrated that genetically different Symbiodinium clades differentially affect host physiology, resulting in, for example, different heat tolerances or growth rates (Fitt 1985, Baker et al. 2004, Little et al. 2004, Berkelmans \& van Oppen 2006, Abrego et al. 2008). Since Symbiodinium partners exude substantial amounts of assimilated carbon into the mucus layer (Ikeda \& Miyachi 1995), variation in Symbiodinium clades may affect the composition of coral mucus and, subsequently, select variant coral-associated microbiota, partly explaining the species-specific associations in previous studies (Littman et al. 2009). However, clone libraries, DGGE and tRFLP analyses all consistently showed no conserved diversity or specific associations for Clade C1 versus D infected Acropora tenuis and A. millepora colonies at 9 mo. We therefore conclude that the coral's Symbiodinium clade is not a principal factor driving differences in microbial partners in early developmental stages of these 2 coral species and that, at this early developmental stage, the high bacterial diversity found compared to that of adults indicates that no selection of bacterial partners is taking place. A lack of specificity for microbial associations in early ontogeny has also been observed sin the initial uptake of different Symbiodinium types. For instance, the apparent specificity for Strain C1 observed in adult populations of $A$. tenuis is not present in the early stages of infection (Little et al. 2004). New recruits take up both $\mathrm{C} 1$ and D strains and become dominated by Symbiodinium Clade D after $\sim 4$ mo, although Type C1 eventually dominates, either through competition between different symbiont types or host mediated upregulation (Little et al. 2004). It is noteworthy that the establishment of Symbiodinium partners in early ontogeny is a dynamic process, and it can take up to $3 \mathrm{yr}$ to establish adult patterns of Symbiodinium-coral symbioses (Abrego et al. 2009).

It has been proposed that a lack of specificity for symbionts may serve as an adaptive mechanism for establishing associations with multiple symbionts that have different physiological characteristics (Little et al. 2004, Abrego et al. 2009). Similarly, multiple bacterial types may settle on new corals until coral-bacterial interactions lead to an established community best suited for particular environmental conditions. This may explain why certain ribotypes appear with different levels of dominance within the juvenile profiles, such as Stenotrophomonas- and Brevundimonasrelated sequences, observed frequently in DGGE profiles and in higher proportions in some clone libraries. Furthermore, phylogenetic analysis of dominant clone 
sequences from both adults and juveniles showed some similarities. Many sequences retrieved from adult corals were also found in the 9 mo old juvenile libraries (Fig. S1), suggesting that the juveniles may be in the process of establishing their adult associations. However, many sequences retrieved from adult corals were not detected in juvenile clone libraries, possibly suggesting a successional process whereby the diverse bacterial communities are gradually replaced by the adult associates. Such a winnowing process (Nyholm \& McFall-Ngai 2004) is similar to patterns emerging for the establishment of Symbiodinium endosymbiosis (Rodriguez-Lanetty et al. 2006) and may reduce the comparatively high bacterial diversity of juveniles and result in the establishment of conserved adult bacterial communities. Apprill et al. (2009) similarly found distinct communities of bacteria associated with oocyte bundles, spawned eggs and planula larvae of Pocillopora meandrina, supporting the observation that bacterial associates change throughout early developmental stages. However, planula larvae only internalized 1 Roseobacter clade after $79 \mathrm{~h}$, indicating that coral can have specificity for associating with certain bacteria early in development. Future studies are required to examine the dynamics of bacterial associations throughout the full ontogeny of corals from larval stages through adulthood, to monitor the progression and establishment of a stable species-specific bacterial community.

\section{Temperature stress on bacterial associations of juvenile coral}

The greater mortality rates of Acropora tenuis juveniles hosting Clade D Symbiodinium (78\%) in comparison to $\mathrm{C} 1$ juveniles ( $22 \%$ mortality), plus their 3 -fold smaller sizes (1 cm diameter for $\mathrm{D}$ juveniles versus $3 \mathrm{~cm}$ diameter for $\mathrm{C} 1$ juveniles) (Table 1 ) indicate that A. tenuis juveniles harbouring Clade D were less fit and potentially received fewer nutrients for growth. Growth rates observed in the present study are supported by those recorded by Little et al. (2004), which showed a 2- to 3-fold higher growth rate in A. tenuis and A. millepora harbouring Clade C1 compared to Clade D. Clone libraries derived from A. tenuis juveniles harbouring Clade $\mathrm{D}$ possessed, in contrast to Clade C1 juveniles, a higher proportion of clones aligned with $\gamma$-Proteobacteria, with sequences related to Vibrio species constituting the majority of these clones. The DGGE bacterial profiles similarly demonstrated the prominence of Vibrio sp.-related sequences in A. tenuis samples hosting Clade D juveniles that were not apparent in Clade $\mathrm{C} 1$ juveniles. The appearance of Vibrio-like sequences as dominant members of the microbial communities in the seemingly unhealthy Clade D samples is noteworthy given that these organisms are often regarded as opportunistic pathogens in marine systems (Saeed 1995, Li et al. 1999, Kraxberger-Beatty et al. 2006), with some Vibrio species implicated specifically as coral pathogens (Kushmaro et al. 1997, Ben-Haim \& Rosenberg 2002, Ben-Haim et al. 2003, Sussman et al. 2008). Moreover, Vibrio-like sequences retrieved from 1 yr old Clade D samples closely aligned with Vibrio coralliilyticus (Fig. S1), which has been demonstrated to be a temperature-dependent pathogen, causing tissue lysis of Pocillopora damicornis (BenHaim \& Rosenberg 2002, Ben-Haim et al. 2003). Seawater temperatures were between 29 and $30^{\circ} \mathrm{C}$ at the time of sampling, indicating that the corals may have been experiencing thermal stress, increasing their susceptibility to pathogenic infection. For example, it has been demonstrated that Vibrio shiloi can switch on temperature-regulated virulence factors at $28^{\circ} \mathrm{C}$, enabling bacterial infection and coral bleaching (Kushmaro et al. 1997, Ben-Haim et al. 1999, Banin et al. 2001). One study examined bacterial communities associated with corals through a bleaching event and demonstrated a relative increase in Vibrio sp.-related sequences prior to and during the peak stress of the bleaching period (Bourne et al. 2008). However, Vibrio spp. have also been shown to be normal constituents of the bacterial community associated with healthy coral (Littman et al. 2009), and the nitrogen-fixing capabilities of coral-associated Vibrio spp. may be important for the nitrogen cycling within the holobiont (Olson et al. 2009). Therefore, it is likely that Vibrio spp. normally reside on the surface of the coral, with environmental stressors, such as higher seawater temperatures, changing the homeostasis of coral microbial associates and permitting proliferation of these organisms. Nevertheless, the deterioration of coral juvenile health and correlation with Vibrio spp. dominance in clone libraries, as well as their frequency in DGGE bacterial profiles, imply that these organisms potentially play an important role in coral health. Further controlled temperature-stress experiments utilizing corals harbouring different Symbiodinium clades are required to establish whether the entire holobiont is more stable with certain types of Symbiodinium and how Vibrio spp. proliferation affects overall coral health.

The decreased fitness of corals hosting Clade D observed in our study has greater implications for coral resilience to climate change. Previous studies have suggested a higher tolerance to heat for corals associated with Type D (Glynn et al. 2001, Toller et al. 2001, Baker et al. 2004, Fabricius et al. 2004, Rowan 2004, Berkelmans \& van Oppen 2006). For example, Berkelmans \& van Oppen (2006) demonstrated that Acropora 
millepora shifted the dominant symbiont from Clade C2 to D after bleaching, with subsequent experiments showing that corals were more thermally tolerant when hosting Clade D. However, these studies involved species in which Type D is homologous. Abrego et al. (2009) showed that $A$. tenuis, in which Type C1 is homologous, were more thermally tolerant with Clade C1 than with Clade D, suggesting that host factors are also involved in determining heat tolerance. Our results are consistent with this conclusion, indicating the Clade D A. tenuis may be more susceptible to bacterial proliferation under heat stress. Two studies have speculated that the Symbiodinium type may contribute to coral resistance to disease, providing possible explanations for differences in coral communities hosting different clades. Sussman et al. (2009) showed differential susceptibility of Symbiodinium clades to a metalloprotease, suggesting that coral (specifically $A$. millepora) may be more susceptible to photosystem II inactivation when hosting Clade A. However, corals harbouring Clade C1 and D did not show differences in this regard. Stat et al. (2008) found sub-optimal health states of $A$. cytherea harboring Clade A, as well as an increased incidence of disease, compared with coral harbouring Clade C. In addition, they demonstrated significantly higher amounts of carbon released by Clade $\mathrm{C}$ than Clade $\mathrm{A}$, providing evidence for less nutrients passed on to the host and therefore decreased fitness of the host as a mechanism for disease susceptibility. The smaller sizes of juveniles hosting Clade D indicate less nutrient acquisition than those hosting Clade $\mathrm{C} 1$, suggesting a trade-off for corals when hosting Clade D versus C1. Further investigations are required to find possible consequences of corals shifting Symbiodinium type.

\section{CONCLUSIONS}

We conclude that colony age, heat stress and, potentially, the Symbiodinium type may contribute to the establishment and dynamics of bacterial communities associated with the coral holobiont. High and variable bacterial diversity on juvenile corals, as indicated by clone libraries, DGGE and tRFLP analysis, suggest that a winnowing process takes place throughout early developmental stages of juvenile coral growth to establish adult patterns of species-specific bacterial associations. Lower growth rates and higher mortality rates of D juveniles of Acropora tenuis indicate that they are less fit than $\mathrm{C} 1$ juveniles. Concomitant proliferation of Vibrio sp. on corals harbouring Clade D suggests that coral associated with Symbiodinium Type C1 may be less susceptible to opportunistic pathogens during times of environmental stress. Therefore, it is possible that the Symbiodinium clade may be important for supplying corals with enough energy to ensure a stable microbial community when subjected to elevated temperatures.

Acknowledgements. We sincerely thank N. Larsen and E. Howells for their considerable work in settling, infecting and surveying juvenile corals. We also thank D. Abrego for his expertise in establishing coral juveniles and help with field surveys. This research was funded by an ARC DP to B. Willis through the ARC Centre of Excellence for Coral Reef Studies and support from the Centre of Marine Microbiology and Genetics located at AIMS, AIMS@JCU, and funded through a Queensland Government Smart State Infrastructure Grant.

\section{LITERATURE CITED}

Abrego D, Ulstrup KE, Willis BL, van Oppen MJH (2008) Species-specific interactions between algal endosymbionts and coral hosts define their bleaching response to heat and light stress. Proc R Soc Lond B Biol Sci 275:2273-2282

Abrego D, Willis BL, van Oppen MJH (2009) Onset of algal endosymbiont specificity varies among closely related species of Acropora corals during early ontogeny. Mol Ecol 18:3532-3543

Altschul SF, Madden TL, Schaeffer AA, Zhang J, Zhang Z, Miller W, Lipman DJ (1997) Gapped BLAST and PSIBLAST: a new generation of protein database search programs. Nucleic Acids Res 25:3389-3402

Apprill A, Marlow HQ, Martindale MQ, Rappe MS (2009) The onset of microbial associations in the coral Pocillopora meandrina. ISME J 3:685-699

Baker AC, Starger CJ, McClanahan TR, Glynn PW (2004) Corals' adaptive response to climate change. Nature 430: 741

> Banin E, Sanjay KH, Naider F, Rosenberg E (2001) Prolinerich peptide from the coral pathogen Vibrio shiloi that inhibits photosynthesis of zooxanthellae. Appl Environ Microbiol 67:1536-1541

Barnes DJ, Chalker BE (1990) Calcification and photosynthesis in reef-building corals and algae. In: Dubinsky Z (ed) Coral reefs. Elsevier, Amsterdam, p 109-131

- Ben-Haim Y, Rosenberg E (2002) A novel Vibrio sp. pathogen of the coral Pocillopora damicornis. Mar Biol 141:47-55

> Ben-Haim Y, Banin E, Kushmaro A, Loya Y, Rosenberg E (1999) Inhibition of photosynthesis and bleaching of zooxanthellae by the coral pathogen Vibrio shiloi. Environ Microbiol 1:223-229

Ben-Haim Y, Zicherman-Keren M, Rosenberg E (2003) Temperature-regulated bleaching and lysis of the coral Pocillopora damicornis by the novel pathogen Vibrio coralliilyticus. Appl Environ Microbiol 69:4236-4242

- Berkelmans R, van Oppen MJH (2006) The role of zooxanthellae in the thermal tolerance of corals: a 'nugget of hope' for coral reefs in an era of climate change. Proc $\mathrm{R}$ Soc Lond B Biol Sci 273:2305-2312

$>$ Bourne D, Iida Y, Uthicke S, Smith-Kuene C (2008) Changes in coral-associated microbial communities during a bleaching event. ISME J 2:350-363

> Buddemeier RW, Fautin DG (1993) Coral bleaching as an adaptive mechanism - a testable hypothesis. Bioscience 43:320-326

Cantin NE, van Oppen MJH, Willis BL, Mieog JC, Negri AP (2009) Juvenile corals acquire more carbon from high performance algal endosymbionts. Coral Reefs 28:405-414 
Castillo I, Lodeiros C, Nunez M, Campos I (2001) In vitro evaluation of antibacterial substances produced by bacteria isolated from different marine organisms. Rev Biol Trop 49:1213-1221

Chao A (1987) Estimating the population size for capturerecapture data with unequal catchability. Biometrics 43: 783-791

Colwell RK (2006) EstimateS: statistical estimation of species richness and shared species from samples, Version 8. User's guide and application. Available at: http://viceroy. eeb.uconn.edu/estimateS

- Cooney RP, Pantos O, Le Tissier MDA, Barer MR, O'Donnell AG, Bythell JC (2002) Characterization of the bacterial consortium associated with black band disease in coral using molecular microbiological techniques. Environ Microbiol 4:401-413

DeSantis TZ, Hugenholtz P, Larsen N, Rojas M and others (2006) Greengenes, a chimera-checked 16S rRNA gene database and workbench compatible with ARB. Appl Environ Microbiol 72:5069-5072

Fabricius KE, Mieog JC, Colin PL, Idip D, van Oppen MJH (2004) Identity and diversity of coral endosymbionts (zooxanthellae) from three Palauan reefs with contrasting bleaching, temperature and shading histories. Mol Ecol 13:2445-2458

Ferris MJ, Muyzer G, Ward DM (1996) Denaturing gradient gel electrophoresis profiles of 16S rRNA-defined populations inhabiting a hot spring microbial mat community. Appl Environ Microbiol 62:340-346

Fisher RA, Corber AS, Williams CB (1943) The relation between the number of species and the number of individuals in a random sample of an animal population. J Anim Ecol 12:42-58

Fitt WK (1985) Effect of different strains of zooxanthella Symbiodinium microadriaticum on growth and survival of their coelenterate and molluscan hosts. In: Gabrié C et al (eds) Proc 5th Int Coral Reef Congr, Vol 6. Antenne Museum-EPHE, Moorea, p 131

Glynn PW, Mate JL, Baker A, Calderon MO (2001) Coral bleaching and mortality in Panama and Ecuador during the 1997-1998 El Niño-Southern Oscillation event: spatial/temporal patterns and comparisons with the 1982-1983 event. Bull Mar Sci 69:79-109

Good IJ (1953) The population frequencies of species and the estimation to the population parameters. Biometrika 40: 237-264

Heck KL Jr, Van Belle G, Simberloff D (1975) Explicit calculation of the rarefaction diversity measurements and the determination of sufficient sample size. Ecology 56: 1459-1461

Holland SH (1988) A RarefactWin program, Version 1.2. Available at: www.uga.edu/strata/software/

> Hurlbert SH (1971) The non-concept of species diversity: a critique and alternative parameters. Ecology 52:577-586

Ikeda Y, Miyachi S (1995) Carbon dioxide fixation by photosynthesis and calcification for a solitary coral, Fungia sp. Bull Inst Oceanogr 14:61-67

Knowlton N, Rohwer F (2003) Multispecies microbial mutualisms on coral reefs: the host as a habitat. Am Nat 162: $51-62$

Kraxberger-Beatty T, McGarey HJ, Grier DV, Lim V (2006) Vibrio harveyi, an opportunistic pathogen of common snook, Centropomus undecimalis (Bloch), held in captivity. J Fish Dis 13:557-560

Kushmaro A, Loya Y, Fine M, Rosenberg E (1997) Bleaching of the coral Oculina patagonica by Vibrio AK-1. Mar Ecol Prog Ser 147:159-165
Lesser MP, Mazel CH, Gorbunov MY, Falkowski PG (2004) Discovery of symbiotic nitrogen-fixing cyanobacteria in corals. Science 305:997-1000

> Li J, Yie J, Foo RWT, Ling JML, Xu J, Woo NYS (1999) Antibiotic resistance and plasmid profiles of Vibrio isolates from cultured silver sea bream, Sparus sarba. Mar Pollut Bull 39:245-249

Little AF, van Oppen MJH, Willis BL (2004) Flexibility in algal endosymbioses shapes growth in reef corals. Science 304: 1492-1494

> Littman RA, Willis B, Pfeffer C, Bourne D (2009) Diversity of coral-associated bacteria differ with location but not species for three acroporids on the Great Barrier Reef. FEMS Microbiol Ecol 68:152-163

Ludwig W, Strunk O, Klugbauer S, Klugbauer N, Wei-zenegger M, Neumaier J (1998) Bacterial phylogeny based on comparative sequence analysis. Electrophoresis 19: $554-568$

Ludwig W, Strunk O, Westram R, Richter L (2004) ARB: a software environment for sequence data. Nucleic Acids Res 32:1363-1371

Maidak BL, Olsen GJ, Larsen N, Overbeek R, McCaughey MJ, Woese CR (1996) The Ribosomal Database Project (RDP). Nucleic Acids Res 24:82-85

> Marchesi JR, Sato T, Weightman AJ, Martin TA, Wade WG (1998) Design and evaluation of useful bacterium-specific PCR primers that amplify genes coding for bacterial 16S rRNA. Appl Environ Microbiol 64:795-799

Muller-Parker G, D'Elia CF (1997) Interactions between corals and their symbiotic algae. In: Birkeland C (ed) Life and death of coral reefs. Chapman \& Hall, New York, p 96-133

Nyholm SV, McFall-Ngai MJ (2004) The winnowing: establishing the squid-Vibrio symbiosis. Nat Rev Microbiol 2: 632-642

Olson ND, Ainsworth TD, Gates RD, Takabayashi M (2009) Diazotrophic bacteria associated with Hawaiian Montipora corals: diversity and abundance in correlation with symbiotic dinoflagellates. J Exp Mar Biol Ecol 371:140-146

Reshef L, Koren O, Loya Y, Zilber-Rosenberg I, Rosenberg E (2006) The coral probiotic hypothesis. Environ Microbiol 8:2068-2073

> Ritchie KB (2006) Regulation of microbial populations by coral surface mucus and mucus-associated bacteria. Mar Ecol Prog Ser 322:1-14

Ritchie KB, Smith GW (1997) Physiological comparisons of bacterial communities from various species of scleractinian corals. In: Lessios HA, MacIntyre IG (eds) Proc 8th Int Coral Reef Symp, Vol 1. Smithsonian Tropical Research Institute, Balboa, p 521-526

Ritchie KB, Smith GW (2004) Microbial communities of coral surface mucopolysaccharide layers. In: Rosenberg E, Loya Y (eds) Coral health and disease. Springer-Verlag, Heidelberg, p 259-264

> Rodriguez-Lanetty M, Wood-Charlson EM, Hollingsworth LL, Krupp DA, Weis VM (2006) Temporal and spatial infection dynamics indicate recognition events in the early hours of dinoflagellate/coral symbiosis. Mar Biol 149:713-719

Rohwer F, Breitbart M, Jara J, Azam F, Knowlton N (2001) Diversity of bacteria associated with the Caribbean coral Montastraea franksi. Coral Reefs 20:85-91

- Rohwer F, Seguritan V, Azam F, Knowlton N (2002) Diversity and distribution of coral-associated bacteria. Mar Ecol Prog Ser 243:1-10

Rowan R (2004) Thermal adaptations in reef coral symbionts. Nature 430:742

Saeed MO (1995) Association of Vibrio harveyi with mortalities 
in cultured marine fish in Kuwait. Aquaculture 136:21-29 Shannon CE, Weaver W (1963) The mathematical theory of communication. University of Illinois Press, Urbana, IL

Shashar N, Cohen Y, Loya Y, Sar N (1994) Nitrogen-fixation (acetylene-reduction) in stony corals-evidence for coralbacteria interactions. Mar Ecol Prog Ser 111:259-264

Simberloff D (1978) Use of rarefaction and related methods in ecology. In: Dickson KL, Cairns JJ, Livingston RJ (eds) Biological data in water pollution assessment: quantitative and statistical analyses. American Society for Testing and Materials, Philadelphia, PA, p 150-165

Smith CJ, Danilowicz BS, Clear AK, Costello FJ, Wilson B, Meijer WG (2006) T-Align, a web-based tool for comparison of multiple terminal restriction fragment length polymorphism profiles. FEMS Microbiol Ecol 54:375-380

Stat M, Morris E, Gates RD (2008) Functional diversity in coral-dinoflagellate symbiosis. Proc Natl Acad Sci USA 105:9256-9261

Sussman M, Willis BL, Victor S, Bourne DG (2008) Coral

Editorial responsibility: John Choat,

Townsville, Australia pathogens identified for white syndrome (WS) epizootics in the Indo-Pacific. PLoS One 3:1-14

Sussman M, Mieog JC, Doyle J, Victor S, Willis BL, Bourne DG (2009) Vibrio zinc-metalloprotease causes photoinactivation of coral endosymbionts and coral tissue lesions. PLoS One 4:1-14

Toller WW, Rowan R, Knowlton N (2001) Repopulation of zooxanthellae in the Caribbean corals Montastraea annularis and $M$. faveolata following experimental and disease-associated bleaching. Biol Bull 201:360 doi:10.2307/ 1543614

van Oppen MJH, Palstra FP, Piquet AMT, Miller DJ (2001) Patterns of coral-dinoflagellate associations in Acropora: significance of local availability and physiology of Symbiodinium strains and host-symbiont selectivity. Proc R Soc Lond B Biol Sci 268:1759-1767

Williams WM, Viner AB, Broughton WJ (1987) Nitrogenfixation (acetylene-reduction) associated with the living coral Acropora variabilis. Mar Biol 94:531-535

Submitted: March 23, 2009; Accepted: June 26, 2009

Proofs received from author(s): August 25, 2009 